\title{
Neuroendocrine tumor of the rectum detected incidentally: A case report
}

\section{İnsidental olarak saptanan rektum nöroendokrin tümörü: Olgu sunumu}

\author{
Orhan Üreyen ${ }^{1}$, Enver İlhan ${ }^{1}$, Uğur Gökçelli ${ }^{1}$, Enver $\operatorname{Vardar}^{2}$ \\ ${ }^{1}$ Sağlık Bilimleri Üniversitesi, İzmir Bozyaka Eğitim ve Araştırma Hastanesi, Genel Cerrahi Kliniği, \\ ${ }^{2}$ Sağlık Bilimleri Üniversitesi, İzmir Bozyaka Eğitim ve Araştırma Hastanesi, Patoloji Departmanı
}

Dergiye Ulaşma Tarihi:13.08.2016 Dergiye Kabul Tarihi:28.11.2016 Doi: 10.5505/aot.2017.13007

\begin{abstract}
ÖZET
Nöroendokrin Tümörler (NET) kromaffin benzeri hücrelerden köken alır. Nadiren görülürler, vücudun herhangi bir yerini tutabilirler. Görüldükleri bölgeye ve organa göre farklı klinik ile ortaya çıkarlar. Çoğunlukla benign seyirlidirler ancak agresif de seyredebilirler. Rektal NET ler \%90 oranında asemptomatik olup insidental olarak kolonoskopi esnasında saptanırlar. Burada Fournier Gangreni nedeniyle ostomi açılan ve ostomisinin kapatılması öncesinde rutin uyguladı̆̆ımız kolonoskopi esnasında rektumda saptanan nöroendokrin tümör (NET G1) olgusunu sunduk.
\end{abstract}

Anahtar Kelimeler: Nöroendokrin tümör, kolonoskopi, rektum

\begin{abstract}
Neuroendocrine tumors (NET) are originated from chromaffin-like cells. They are rarely seen anywhere in the body and they occur with many different clinical situations by regions and organs where they appear. They are mostly benign but they can be aggressive. Rectal NETs are asymptomatic $90 \%$ and they are detected incidentally during colonoscopy. We presented a case that was opened ostomy for fournier's gangrene and diagnosed NET during routine colonoscopy, before the closing ostomy.
\end{abstract}

Keywords: neuroendocrine tumor, colonoscopy, rectum

\section{Giriş}

Nöroendokrin Tümörler (NET) kromaffin benzeri hücrelerden köken alır. Nadiren görülürler, vücudun herhangi bir yerini tutabilirler. Görüldükleri bölgeye ve organa göre farklı klinik ile ortaya çıkarlar (1). Çoğunlukla benign seyirlidirler ancak agresif de seyredebilirler. Rektal NET'ler \%90 oranında asemptomatik olup genellikle insidental olarak saptanırlar.

Rektal NET'ler tüm gastrointestinal NET'lerin \%34' ünü oluşturur ve rektum en s1k görülen bölgeler arasında yer almaktadır. Klinik semptomları, hastalığın görüldüğü organ ve endokrin fonksiyonlarına göre değişkenlik göstermektedir (2). Sürveyans analizlerinde gastrointestinal NET'lerin son yıllarda insidansının arttığı görülmektedir. Rektal NET'ler yıllık tüm NET'lerin \%17.1'ini oluşturur (3). Aynı kolon kanseri gibi standart tedavisi rezeksiyondur. Ancak lenf nodu metastazı varlığı, radikal rezeksiyon ya da lokal eksizyon yapılmasinın en önemli belirleyicisidir (1). Beş yıllık sağkalım lokalize hastalıkta \%90'larda iken bölgesel hastalıkta \%60'larda ve özellikle karaciğer gibi uzak organlara yay1lımda ise \%24'lere inmektedir (4). Burada insidental olarak saptanan rektal NET olgusunun yönetimini sunduk.

\section{Olgu}

Fournier Gangreni (FG) olan ve tedavisi için sigmoid loop kolostomi açılan 38 yaşında erkek olgunun FG tedavisi tamamlandıktan sonraki 4. ayında, ostomisi kapatılmadan önce yapılan kontrol kolonoskopisinde, rektum 7-8. $\mathrm{cm}$ arasında $10 \mathrm{~mm}$ çapında sesil, polipoid oluşum saptand. Polipektomi uygulandi. Histopatolojik olarak; lamina propria ve submukozada yerleşmiş yaklaşı $4,5 \mathrm{~mm}$ çapında 
nöroendokrin tümör (NET G1) saptandı. Tümör koter sınırına çok yakın olmakla birlikte 50 mikronluk salim alan mevcuttu. Tümörde nekroz izlenmedi. İmmünohistokimyasal yöntemle uygulanan synaptofizin $(+)$, kromogranin (+), cd56 (+), cd57 (+), nse (+), p53 (-), Ki 67 proliferasyon indeksi \%2'nin altında (+), klasik 1şık mikroskobisinde 10 büyük büyütme alanında 2 'nin altında mitotik figür saptand1, egfr (-), mlh1 (+), pms2 (-), msh $2(+)$, msh $6(+)$ " olarak raporlandı (Resim $1,2,3)$. Tarama amaçlı üst ve alt gastrointestinal sistem endoskopisi, endorektal ultrasonografi, batın manyetik rezonans görüntüleme, octreotid sintigrafisi ve uzak organ metastaz taramas1 olağan idi. Olgu tümör konseyinde görüşülerek takibe alındı. Ostomisi kapatıld 1 ve 20 aydır sorunsuz takip edilmektedir.

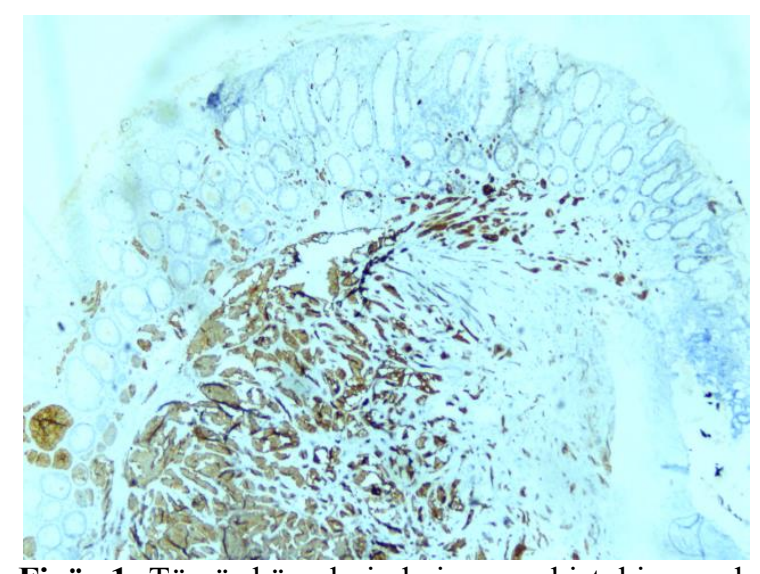

Figür 1: Tümör hücrelerinde immunohistokimyasal olarak sinaptofizin pozitifliği (Sinaptofizin - x20).



Figür 2: Submukozada ve lamina propriada da yer alan solid ve tubuler yapılar oluşturan tümör hücreleri (HE - x100). Sağ üst köşede ise büyük büyütmede nukleusların görünümü (HE - x400).

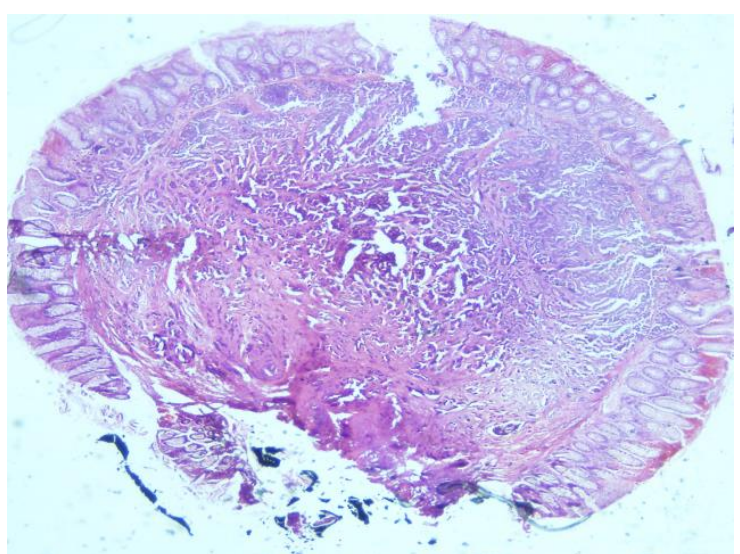

Figür 3: Küçük büyütmede lezyonun polipoid natürü, sağda tabanda yer alan kotere ait sınır izlenmektedir (HE - x20)

\section{Tartışma}

Rektum, NET'ler için ince bağırsak ve kolondan (apendiks dahil) sonra en s1k görülen 3. bölgedir. Buna rağmen tüm rektal tümörlerin \%1-2'sini oluştururlar. Rektal karsinoidler epitelyal tümörler olup glandların derin kısmına yerleşir. Tipik olarak muskularis mukozadan submukozaya ulaşır ve submukozal tümör gibi görünürler (5). Olgumuzda benzer özellikte olup yer yer mukoza görülse de genel olarak submukozaya yerleşmişti.

Rektal NET'lerin son 30 yılda görülme sıklığ 10 kat artmıştır. Buna endoskopik lezyon karekteristiklerinin daha iyi tanımlanması, kolonoskopiye ulaşımın kolaylaşması, kolorektal kanser tarama programlarının olması, kanser ve histoloji kayıtlarının daha dikkatli olarak veri tabanlarına aktarılmasıyla açıklanabilmektedir. Vakaların \%50'den fazlasının çoğunluğu insidental olarak endoskopi esnasında saptanmaktadır. Çok az bir kısmı karın ağrısı, rektal kanama, kilo kaybı ve anorektal semptomlarla başvurmaktadır (3). Ayrıca karsinoid sendrom (cillte kızarma, ishal, karın ağrısı vb.) bulguları oldukça nadir görülmekte olup, olgumuzda da literatürle uyumlu olarak herhangi bir semptom ya da karsinoid sendrom bulgusu yoktu (5).

Endoskopik olarak rektal NET'ler adenomotöz ya da hiperplastik polipler gibi çok farklı görünümde olabilirler. Tipik özellikleri ise küçük, düz ve sapsız oluşlarıdır. Sıklıkla 1 cm altında, normal ya da mukozanın sarımsı renk değişikliği şeklindedirler. Bu lezyonlar genel olarak mukozanın derin tabakalarında ortaya çıkar ve mukozal yüzde bozulma 
yapmazlar. Genellikle anal marjinden $5 \mathrm{~cm}$ proksimalde bulunur (5). Olgumuz, endoskopik olarak; görünüm, yerleşim ve boyut açısından rektal NET için tipik bulgulara sahipti.

$\mathrm{Bu}$ tümöre sahip hastaların sağ kalımını; tümör boyutu, lenf nodu metastazı, uzak organ metastaz1, histolojik grade gibi birçok faktör belirlemektedir. Yoon ve arkadaşları (5) 5 yıllık sağ kalımı tümör boyutu $\leq 1 \mathrm{~cm},>1-\leq 2 \mathrm{~cm}$ ve $>2 \mathrm{~cm}$ nin üzerinde, sirasıyla $\% 96.7, \% 87.7$, ve $\% 50$ bulmuşlardır. Tümörün uzak organ yayılımındaki en önemli faktör tümör çapı olarak bilinmektedir. Eğer 1 $\mathrm{cm}$ altında ise metastaz oran $1 \% 1.7$ ile $\% 3.4$ arasında değişmektedir (5). Bu durum bize tümör çap1 ne olursa olsun malign potansiyeli olduğunu ve her olguda uzak organ taramas1 yapmamı gerektiğini göstermektedir. Olgumuzda tümör çapı $4.5 \mathrm{~mm}$ olmasına rağmen uzak organ taraması yapıldı ve herhangi bir metastaz saptanmadi.

$\mathrm{Bu}$ tümörler mitoz sayıs1 ve $\mathrm{Ki} 67$ indeksine göre Grade 1, 2 ve 3 alt gruplarına ayrılmaktadır. Grade 1 ve 2 iyi diferansiye nöroendokrin tümör, grade 3 ise yüksek-grade nöroendokrin karsinom olarak adlandırılmaktadır (6). Olgumuzda Ki $67 \%$ 2 'nin altında ve mitoz sayıs 10 büyük büyütme alanında ikinin altında belirlendi. Olgumuz bu bulgularla en çok görülen ve en iyi histolojik tip olan grade 1 grubunda idi (3).

Prognoz araştırması yapan Weinstock ve arkadaşları (4) asemptomatik olguların prognozunun daha iyi olduğunu savunsalar da, Li ve arkadaşları (1) çalışmalarında, iki grup arasında fark olmadığını göstermiştir. Ancak bu çalışmada semptomatik olguların \%81.7'si evre 1 olgulardan oluşmaktadır. $\mathrm{O}$ yüzden semptomların varlığında, hastalığın prognozu net olarak bilinmese de, erken evrede tespit edilmesinin en önemli faktör olduğu aşikardır. Tümör boyutu arttıkça uzak organ metastazı yaygin hale gelmektedir. Bununla birlikte $1 \mathrm{~cm}$ altında olsa bile, halen \%1.7 ile 3.4 malign potansiyel taşımaktadır (7).

Tümör çapı, histolojik tip ve lenf nodu durumuna bakıldığında olgumuz oldukça iyi prognostik duruma sahipti. Rektal NET'ler genel olarak iyi seyretseler de en temel prognostik faktör olan tümör boyutunun artmadan saptanması hayati öneme sahiptir. Olgumuz her ne kadar FG gibi morbidite ve mortalitesi yüksek bir hastalık geçirmiş olsa da bu hastalığın tedavisi nedeniyle uygulanan ostomi sonrasinda yapilan kontrol kolonoskopisinde NET saptanması bir şans olarak değerlendirilmiştir.

Tedavisinde tümörün rezeksiyonu primer yaklaşımdır. Cerrahi tedavide tümör boyutu, lenf nodu metastazı ve invazyonun derinliği göz önüne alınarak endoskopik rezeksiyon, lokal eksizyon ve radikal rezeksiyon seçenekleri uygulanmaktadır. Endoskopik olarak çıkarılacak tümörlerde lenf nodu pozitifliği olmaması, mukoza ve submukoza altına inmemesi, tümör boyutunun küçük olması ve parça parça değil de bir bütün olarak çıkarılabilecek durumda olması gerekmektedir. Cerrahi tedavi seçiminde ise lokal (Transanal) rezeksiyon için tümörün $2 \mathrm{~cm}$ ve altında olmasi, lenf nodu tutulumu olmaması, düşük gradeli, derin yerleşimli olmaması gerekmektedir. Eğer tümörde muskularis propria tutulumu, lenf nodu tutulumu, $2 \mathrm{~cm}$ den büyük tümör çapı, yüksek grade (grade 3 ), invazyon varlığ yada ileri evre (Evre 2-4)'den en az birinin olması halinde total mezorektal eksizyonla beraber abdominoperineal ya da low anterior rezeksiyon önerilmektedir (3).

Sonuç olarak; rektal NET nadiren de olsa karşımıza çıkabilmektedir. Kolonoskopide saptanan lezyonlarda rektal NET akilda tutularak; küçük lezyonlarda salim cerrahi sınır ile endoskopik eksizyon her zaman ana hedef olmalıdır. Takip ve tedavisinde; evresinin yanı sıra hayati öneme sahip olan diğer prognostik faktörleri de göz önüne alarak uygun cerrahi yöntemin planlanması gerekmektedir.

\section{Kaynaklar}

1. Li P, Wu F, Zhao H, et al. Analysis of the factors affecting lymph node metastasis and the prognosis of rectal neuroendocrine tumors. Int $\mathbf{J}$ Clin Exp Pathol. 2015;8:13331-8

2. Wang YZ, Chauhan A, Hall MA. Adjuvant intraoperative post-dissectional tumor bed chemotherapy-A novel approach in treating midgut neuroendocrine tumors. J Gastrointest Oncol. 2015;6:254-8

3. Basuroy R, Haji A, Ramage JK, Quaglia A, Srirajaskanthan R. Review article: the investigation and management of rectal neuroendocrine tumours. Alimentary Pharmacology \& Therapeutics. 2016;44:332-45

4. Weinstock B, Ward SC, Harpaz N, Warner RRP, Itzkowitz S, Kim MK. Clinical and Prognostic Features of Rectal Neuroendocrine Tumors. Neuroendocrinology. 2013;98:180-7 
5. Yoon SN, Yu CS, Shin US, Kim CW, Lim SB, Kim JC. Clinicopathological characteristics of rectal carcinoids. Int J Colorectal Dis. 2010 25:1087-92

6. Washington K, Tang LH, Berlin J, et al. Protocol for the Examination of Specimens From Patients With Neuroendocrine Tumors (Carcinoid Tumors) of the Colon and Rectum. Endocrine.
Neuroendocrine Tumors of the Colon and Rectum. College of American Pathologists (CAP). 2013 (www.cap.org/cancerprotocols)

7. Fahy BN, Tang LH, Klimstra D, et al. Carcinoid of the rectum risk stratification (CaRRs): a strategy for preoperative outcome assessment. Ann Surg Oncol 2007:14:1735-43 